\title{
EVALUATION OF RADIOPROTECTIVE EFFECT OF CARNOSINE ( $\beta$ - ALANYL-1- HISTIDINE) ON THE WOUND HEALING IN RATS
}

\author{
AVALIAÇÃO DO EFEITO RADIOPROTETOR DA CARNOSINA (ß-ALANIL-1- HISTIDINA) \\ NO PROCESSO DE CICATRIZAÇÃO EM RATOS
}

\author{
Rosana Aramaki TANAKA ${ }^{1}$, Flávia Maria de Moraes RAMOS'소 , Solange Maria de ALMEIDA², \\ Mário Roberto VIZIOLI², Frab Norberto BÓSCOLO²
}

1- DDS Msc, Oral Radiology, Department of Oral Diagnosis, Dental School, State University of Campinas, Piracicaba, SP, Brazil. 2- DDS PhD, Oral Radiology, Department of Oral Diagnosis, Dental School, State University of Campinas, Piracicaba, SP, Brazil.

Corresponding address: Flávia Maria de Moraes Ramos - Oral Radiology, Piracicaba Dental School, UNICAMP - Av. Limeira, 901. Areão CEP: 13414-018 -Piracicaba/SP, Brazil - Tel.: 019-3412-5327 - e-mail: flaviamaria@fop.unicamp.br

Received: August 12, 2004 - Modification: May 02, 2005 - Accepted: June 29, 2005

\begin{abstract} $T_{\text {he purpose of this study was to evaluate the radioprotective effect of carnosine ( } \beta \text { - alanyl-1-histidine) on the wound }}$ healing in rats. Therefore, 48 male rats were submitted to a surgical procedure to perform a rectangular wound in the anteriordorsal region. The animals were divided into 4 experimental groups randomly chosen: control; irradiated; carnosine irradiated and carnosine group. The irradiated and carnosine irradiated group were exposed to a dose (6Gy) of gamma irradiation, in the whole body, 72 hours after surgery. The carnosine and carnosine irradiated groups, in addition to the surgical procedure and the irradiation, received two doses of carnosine aqueous solution, the first one being injected 48 hours after surgery, and the second one 1 hour and 30 minutes before irradiation. The tissue repair of the 4 groups was evaluated at 4, 7, 14, and 21 days after inflicting the wound, by morphological, histochemical and histophysical methods. At all examined periods, it could be observed that the animals from the carnosine irradiated group presented a better developed granulation tissue than the irradiated group and closely similar to that of the control group. Thus, under the experimental conditions used, it was possible to conclude that carnosine is an effective radioprotective substance.

Uniterms: Radiation, ionizing; Radiation-protective agents; Carnosine; Wound healing.
\end{abstract}

\section{RESUMO}

objetivo deste estudo foi avaliar o efeito radioprotetor da carnosina ( $\beta$-alanil-1-histidina) no processo de cicatrização em ratos. Para isto, 48 ratos machos foram submetidos a um procedimento cirúrgico para realização de uma ferida retangular na região dorsal anterior. Os animais foram divididos aleatoriamente em 4 grupos experimentais: controle, irradiado, carnosina irradiado e carnosina. Os grupos carnosina e carnosina irradiado foram exposto a uma dose de corpo todo de 6 Gy de radiação gama, 72 horas após a cirurgia para confecção da ferida. O grupo carnosina e carnosina irradiado, adicionalmente, ao procedimento cirúrgico e a irradiação, receberam duas doses de solução aquosa de carnosina, a primeira sendo injetada 48 horas após a cirurgia, e a segunda 1 hora e 30 minutos antes da irradiação. A reparação tecidual nos 4 grupos foi avaliada 4, 7, 14 e 21 dias após a realização da ferida, por métodos morfológicos, histoquímicos e histofísicos. Em todos os períodos examinados, pode ser observado que os animais do grupo carnosina irradiado apresentaram um melhor desenvolvimento do tecido de granulação do que o grupo irradiado e muito similar ao do grupo controle. Logo, de acordo com as condições experimentais usadas, foi possível concluir que a carnosina é uma substância radioprotetora efetiva.

Unitermos: Radiação ionizante; Protetores contra radiação; Carnosina; Cicatrização de feridas. 


\section{INTRODUCTION}

Wound healing is a complex process, which is commonly divided into three phases, including invasion of inflammatory cells, proliferation of tissue repairing cells and tissue remodeling. Any alteration in some of these phases will inevitably cause an abnormal tissue repair process ${ }^{22}$. Any of these phases will be altered or retarded when radiation is involved. The effects of ionizing radiation are mediated by the formation of free radicals, which are highly reactive, removing hydrogen atoms from fatty acids, causing lipid peroxidation and consequently cell death ${ }^{9}$. These modifications could be caused by vessel or fibroblast alterations, including: hypoxia, inefficient collagen production and reduction of proliferation capacity of local tissues, which become less capable of reacting to the inflammatory stimulation ${ }^{15,19,28}$.

The fibroblasts, vascular endothelial cells, keratinocytes and granulation tissue formation are fundamental to the wound healing process ${ }^{17}$. Radiation causes an irregular proliferation of endothelial cells, originating capillaries with different forms and diameters, leading to a transitory increase of permeability ${ }^{2}$. The reduction of granulation tissue thickness, which becomes less cellular in open wounds, thus delaying the formation and maturation of the collagen, was observed when it was submitted to radio-therapeutic doses $^{16}$. The main histomorphological alterations caused in wound healing by postoperative irradiation, were retarded fibroblast growth, alterations in their development with production of atypical cells, formation of fibrin which persisted for a longer than normal time and reduction of the number of vessels ${ }^{12,24}$.

The role of antioxidants in reducing the deleterious effects of ionizing radiations on the tissue repair process has already been studied ${ }^{32}$. The radio-protective effect of substances, such as vitamin E, on wound healing in irradiated rats was also demonstrated on the tissue repair process after 6 Gy of electron irradiation ${ }^{14}$. The action of carnosine in stimulating the normal tissue repair process was reported and its affinity for hydroxyl and capacity to reduce the intermediate products of oxidative free radicals in wound tissues and blood serum was also pointed out ${ }^{1,5,11,18,26,27}$.

This study aimed to evaluate the possible protective effect of carnosine on the wound healing in rats' whole body exposed to gamma radiation, observing the development of granulation tissue by morphologic, histochemistry and histophysical methods.

\section{MATERIALAND METHODS}

Animals. Forty-eight male rats (Rattus norvegicus, albinus Wistar) aged between 60 - 90 days and weighing approximately 300 grams were used. The animals were kept in polycarbonate cages under an alternating $12 \mathrm{~h}$ light/dark cycle and maintained on laboratory chow and water ad libitum.

Experimental design. The experimental procedures consisted of six phases: anesthesia; surgical procedure; irradiation; achievement of the specimen and slide preparations.

The animals were divided into four experimental groups as follows:

Control group (CG): these animals were only submitted to the surgical procedure. Irradiated (IG): these animals were submitted to a surgical procedure and to a whole-body irradiation, 72 hours after the wound was made.

Carnosine Irradiated group (CaIG): these animals received two i.p. doses of aqueous carnosine solution (LCarnosine Sigma-Aldrich) $150 \mathrm{mg} / \mathrm{Kg}$. The first one was administered 48 hours after the wound and the second one, 1 hour and 30 minutes before the whole-body irradiation;

Carnosine group $(\mathrm{CaG})$ : the animals from this group were submitted to the wounding surgery and received two doses of aqueous carnosine solutions, administered in the same way as in group CaIG. These animals were not irradiated.

Surgical procedure. Rats were i.p. anesthetized with thiazine hydrochloride $(10 \mathrm{mg} / \mathrm{kg})$ and ketamine hydrochloride $(100 \mathrm{mg} / \mathrm{Kg})$ and a wound of $2.0 \times 1.0 \mathrm{~cm}$ in size was made in the anterior dorsal region of each animal and at a distance of approximately $1.0 \mathrm{~cm}$ to the right of the spine. The depth of each incision was approximately $0.2 \mathrm{~cm}$, having as a reference the muscular tissue at the base of the wound and the presence of the dermis at its edges.

Irradiation. Rats were i.p. anesthetized with thiazine hydrochloride $(10 \mathrm{mg} / \mathrm{kg})$, and ketamine hydrochloride $(100 \mathrm{mg} / \mathrm{Kg})$ and the whole-body irradiated, 72 hours after the surgical procedure, with a single exposure of 6Gy delivered by a Cobalt therapy tube (Alcyon II) with an output of $84 \mathrm{cGy} / \mathrm{min}$. The distance to target was $80 \mathrm{~cm}$. Irradiation was done on the 3rd day of tissue repair, because this period is related to the cell proliferation phase of healing, characterized by the fibroblasts and endothelial cells migration.

The tissue repair process was evaluated at 4, 7, 14 and 21 days after the surgical procedure. Each part of tissue contents, the wound or the scar surrounded by normal tissue was removed, correctly fixed and paraffin-embedded. Sections of $5 \mathrm{~mm}$ thickness were obtained and stained with hematoxylin-eosin, in order to evaluate the development of the newly formed tissue. Mallory fibroglia method according to Edwards ${ }^{8}$ and Picrosirius staining to evaluate collagen birefringence under polarized light microscopy were also performed.

Sections were also submitted to the toluidine blue $\mathrm{pH} 4$ reaction, which allows the macromolecular organization of granulation tissue to be evaluated, using the observations through linear dicroism by means of polarization microscopy ${ }^{3}$. This phenomenon is essential for detecting the presence or absence of macromolecular orientation of the tissue evolution. The observations under light and polarized microscopy were done through a Zeiss-Pol 01 photomicroscope.

The objective of histophysical methods is the quantitative analysis of collagen fiber birefringence. For this purpose, Zeiss Axiolab microscopy connected to a micro 
camera (Sony CCD IRIS/RGB Collor- Japan) was used, and the slides stained with picrosirius were analyzed. The fields of the sections were measured in five regions each. The evaluation was done on the $4^{\text {th }}$ and $7^{\text {th }}$ days and based on these measurements, the relative means of each group were obtained for submission to statistical analysis.

The morphometric study for counting the fibroblast number was performed under light microscopy, ZEISS Germany, to high-power view (x400) by means of an ocular containing reticule lens PK 8 x mn, Zeiss, West Germany. The fibroblast count was carried out in all the groups on the $4^{\text {th }}$ and $7^{\text {th }}$ day, 10 fields having been evaluated in each slide. From the results of these measurements, the relative means of each group were calculated by statistical analysis.

For statistical analysis, data were initially evaluated using ANOVA. Significant differences were resolved with the Tukey test, with significant p-value $<0.05$.

\section{RESULTS}

\section{Morphological Analysis}

The morphological analysis of CG performed by HE staining was able to demonstrate that on the $4^{\text {th }}$ day the wound was very large, completely covered by a necrotic crust, containing remaining cellular portions, fibrin and coagulated blood, whose function is to protect the subjacent tissue. The inflammatory infiltrate was composed mainly of neutrophils and lymphocytes. In the IG the wound area was also large; the crust was thicker when compared to the control group, with a larger amount of accumulated necrotic material. The granulation tissue presented little organization, with few fibroblasts and a smaller number of vessels and newly formed collagen fibers. In the CaIG, the tissue analyzed was similar to the control group, with a thin superficial necrotic layer and immediately below it, an inflamed zone. The CaG showed very similar aspects to the control group.

On the $7^{\text {th }}$ day, the CG presented a reduction in the size of the wound area, with no crust, which was replaced by a thin superficial necrotic layer. The granulation tissue below presented fibroblastic and angioblastic proliferation, showing newly formed capillary vessels corresponding to the surface. In the IG the wound area had also diminished, however the necrotic crust was still present to the full extent. Below the crust, an acute inflammatory infiltrate still remained. The granulation tissue showed a delayed aspect, showing no capillary vessel organization, and fibroblastic proliferation was poor when compared to the control group (Figure 1A). In the CaIG, the granulation tissue presented evidence of better development than the IG, but slightly less than the control group. The functional capillaries were shown to be present in number and degree of evolution similar to that of the CG. In the CaIG, the analyzed tissue was similar to the control group, both in granulation tissue evolution and in epithelial proliferation (Figure 1B).

Around the $14^{\text {th }}$ day, the wound area in the CG was already totally covered by epithelium, with a keratin layer formation, which demonstrates epithelial tissue maturation. The granulation tissue showed few fibroblastic cells and blood capillaries, becoming fibrous. In the IG, the granulation tissue was shown to be still delayed in relation to the control group. The CaIG was observed to present a slower development process when compared to the control, but more developed than IG. The CaG showed similar aspects to the control group, both in epithelial and granulation tissue maturation and rate of development.

On the $21^{\text {st }}$ day, CG presented a completely healed wound, sufficiently covered by a functional epithelium, almost reaching the normal tissue appearance, also with the presence of cutaneous appendices. The IG presented the tissue repair process still delayed in relation to all groups, with minor retraction and fibrousness. In the CaIG, the tissue development was similar to the CG. The CaG also presented similar aspects to the control group.

\section{Quantitative Analysis of Fibroblasts}

The relative means for each group after being submitted to statistical analysis may be seen in Figure 2.

\section{Mallory Method for Fibroglia}

Fibroglia is evident in granulation tissues with high rate of proliferation before they become fibrous. Therefore, this method was used only on the $4^{\text {th }}$ day of tissue evolution. In the CG, CaG and CaIG (Figure 1C) it could be seen that there was a large fibroglia proliferation. Contrarily, IG has shown almost total absence of fibroglia development (Figure 1D).

\section{Qualitative Evaluation of Birefringence of Collagen Fibers - Picrosirius Staining}

On the $4^{\text {th }}$ day, the CG and $\mathrm{CaG}$ presented a small amount of birefringent collagen fibers, still slim and moderately bright. In the IG the amount of fibers was lower when compared to the control. In the CaIG the collagen fibers showed aspect very similar to the control (Figure 3).

On the $7^{\text {th }}$ day of repair, all groups showed similar aspects in their birefringence, with exception of the IG, which presented fewer collagen fibers with less brightness. On the $14^{\text {th }}$ and $21^{\text {st }}$ days the conditions observed on the $7^{\text {th }}$ day of evolution remained the same, with the IG displaying less birefringence than the other groups.

\section{Quantitative Evaluation of Collagen Fiber Birefringence}

The relative means for each group after being submitted to statistical analysis may be seen in graphs (Figure 3).

\section{Evaluation of Linear Dicroism}

On the $4^{\text {th }}$ day of development none of the groups presented linear dicroism, indicating that at this time, there was still not a sufficient degree of macromolecular 
orientation to induce the phenomenon. When the $7^{\text {th }}$ day of development was analyzed, the CG, CaIG and CaG showed evident dicroism. By contrast, the IG did not show dicroism, which only became evident for this group, on the $14^{\text {th }}$ day of development.

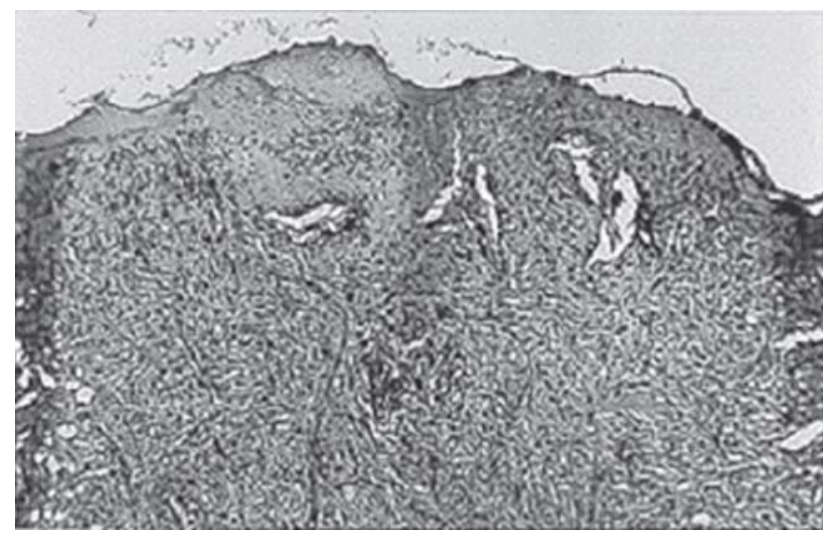

A

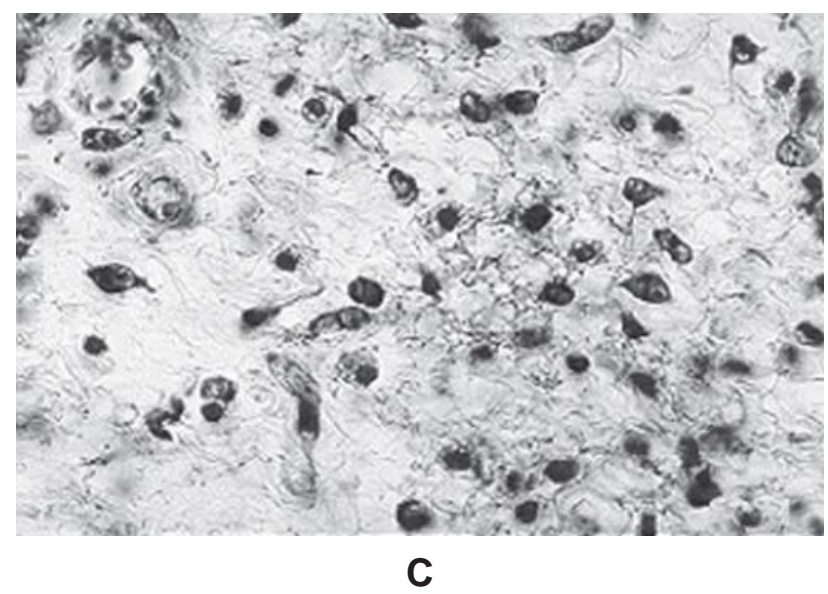

\section{DISCUSSION}

The deleterious effects of ionizing radiation on the tissue repair process were evident when comparing the CG to the IG ${ }^{4,6,12,14-16,19,21,23-25,28,32}$.

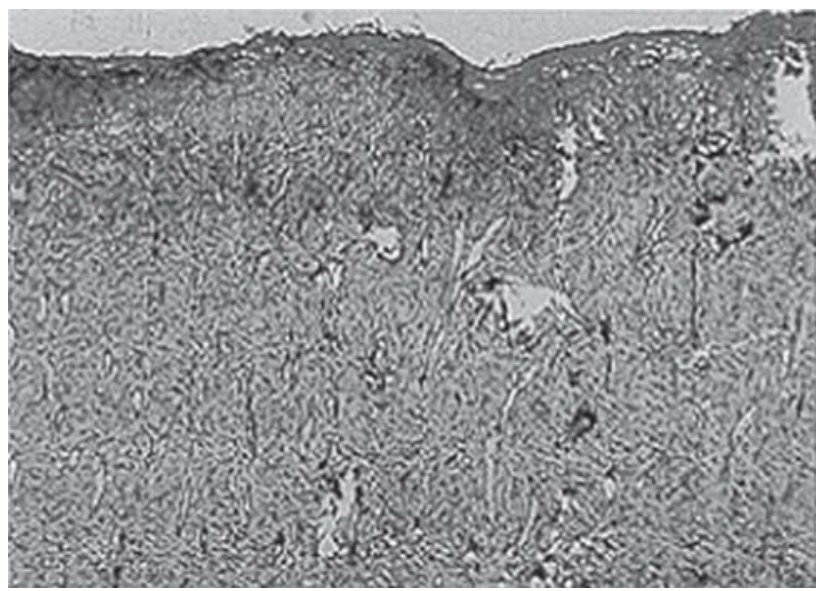

B

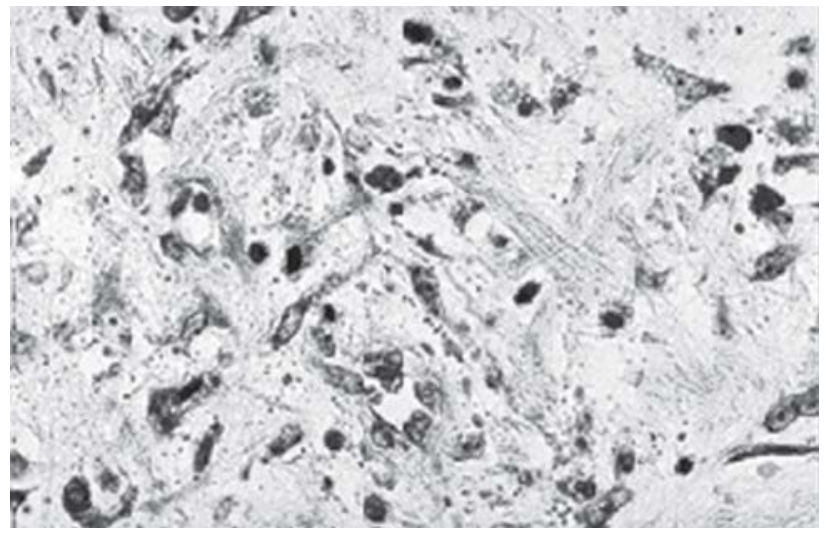

D

FIGURE 1- A- In the IG, on the $7^{\text {th }}$ day, note that granulation tissue showed poor cellular organization; B- CalG, on the $7^{\text {th }}$ day, functional capillaries were shown to be present in higher number and degree of differentiation and the granulation tissue showed more development than the IG (HE, original magnification $\times 250$ ); C- CalG, on the $4^{\text {th }}$ day, showed great fibroglia proliferation; D- IG, on the $4^{\text {th }}$ day, showed almost total absence of fibroglia development (Mallory method, original magnification $\mathrm{x} 250$ )

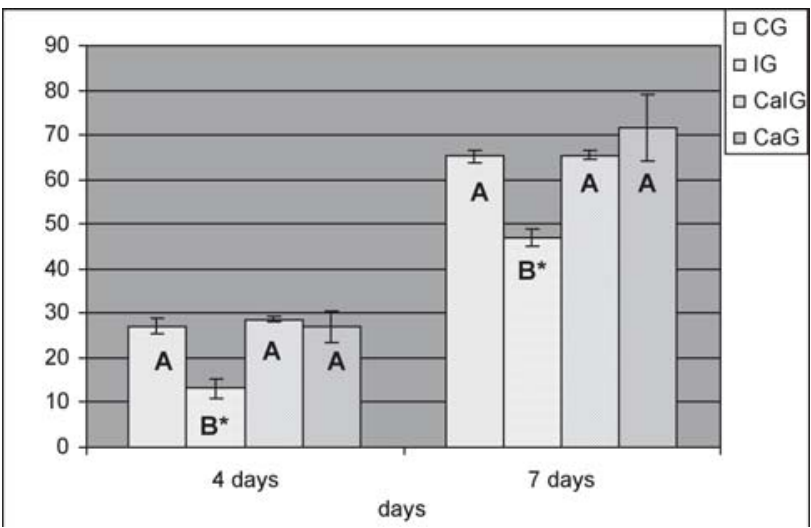

FIGURE 2- Means and standard deviation of the fibroblasts morphometry on the $4^{\text {th }}$ and $7^{\text {th }}$ of tissue evolution. Letters differ statistically between them, with significant $p$-value of $5 \%$, by the Tukey test

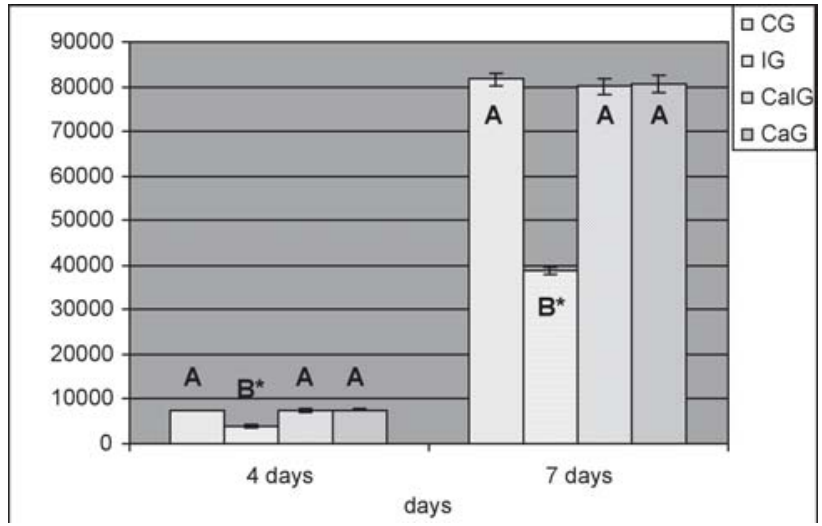

FIGURE 3- Means and standard deviation of the birefringence of collagen fibers $\left(\mathrm{im}^{2}\right)$ on the $4^{\text {th }}$ and $7^{\text {th }}$ day of tissue evolution. Letters differ statistically between them, with significant $p$-value of $5 \%$, by the Tukey test 
In the present study, the morphometry of fibroblasts was analyzed on the $4^{\text {th }}$ and $7^{\text {th }}$ days and significant differences were observed when comparing the IG to the CG and CaIG. Evident modifications could be seen in the IG, such as the diminished number of fibroblasts in the granulation tissue. Thus, the effect of ionizing radiation on damaging tissue repair could be related to the reduction in the number of fibroblasts.

The deleterious effects of ionizing radiation on tissues during healing have been extensively studied. Some authors believe that the damage is related to both fibroblast modifications and vessel complications ${ }^{15,16,25}$. Delay in fibroblast growth has been reported ${ }^{25}$. Functional modification of fibroblasts could influence the production of deficient collagen, which requires a longer maturation time $^{4,7,28,31}$. Other authors ${ }^{12,19}$ observed a reduction in the amount of new vessel formation. It is believed that fibroblasts play a fundamental role in the healing process, because they are responsible for collagen producing protein synthesis. It is accepted that a reduction in the number of fibroblasts decreases collagen synthesis, delaying macromolecular orientation and collagen fiber production, thus retarding the tissue repair process.

Fibroglia is evident in granulation tissue with a high rate of proliferation. In this study, the effect of radiation on delaying this proliferation rate could be observed, when comparing the CG and CaIG to the IG. The IG showed a complete absence of fibroglia development, however the group pre treated with carnosine and irradiated (CaIG) presented a high rate of proliferation similar to CG. The deleterious effect also modified the molecular orientation of collagen, and through picrosirius staining and polarized light microscopy, it could be shown that the IG showed a decrease in birefringence for all evaluation periods, while CaIG presented more organized and shiny collagen fibers, similar to the control group.

Linear dicroism was analyzed and it could be concluded that on the $7^{\text {th }}$ day of IG development, there was no evidence of tissue organization, while the other groups already showed the presence of macromolecular orientation. According to some authors ${ }^{14,29}$ the macromolecular orientation of granulation tissue begins at approximately the $7^{\text {th }}$ day of the tissue repairing process; so, with exception of the IG, all groups presented tissue organization similar to that of the control repair tissue. Thus, a protection given by this antioxidant substance may be advocated.

The action of carnosine in irradiated tissues is related to its affinity for free radicals, mainly for hydroxyl, and its ability to interact with the products of lipid peroxidation, preventing cell membrane damage $e^{4,5,13}$. Carnosine acts as a great hydroxyl radical scavenger, protecting biological structures and playing an important role in the anti-oxidative process $^{1,27}$. The action of carnosine and $b$ alanyl in wound healing in rats treated with hydrocortisone was tested. The exogenous carnosine is degraded through carnosine tissue into histidine and b alanyl. The histidine plays a role in histamine production through hydrocortisone, stimulating the healing process and b alanyl promotes collagen synthesis, accelerating the repair process ${ }^{20}$. As seen in this study, the irradiation process prolongs the inflammatory phase; considering that carnosine administration enables a greater production of histamine, the chemistry mediator responsible for the increase of vascular permeability, its radio-protective effect could be related to the acceleration of the inflammatory phase.

Carnosine promotes the stimulation of the repair process, accelerating granulation tissue development $\mathrm{t}^{10,11,18,30}$. In this experimental study this was not observed. The CaG was similar to the CG, probably because of the amount and period of dose administration. Carnosine was administered twice before the animals were submitted to irradiation and the tissue repair process was already at the end of the inflammatory phase and at the beginning of the proliferation phase. It was observed that the daily administration of carnosine accelerated the production of scar tissue ${ }^{10,20,30}$.

The CaIG presented similar aspects when compared to the control, therefore, carnosine helped to inhibit the deleterious effects of gamma radiation. No effect related to acceleration of tissue repair process was observed, and in comparison to the control, similar aspects were maintained.

\section{REFERENCES}

1- Aruoma OI, Laughton MJ, Halliwell B. Carnosine, homocarnosine and anserine: could they act as antioxidants in vivo? Biochem J. 1989 Dec;264(3):863-9.

2- Baker DG, Krochak RJ. The response of microvascular system to radiation: a review. Cancer Invest. 1989;7(3):287-94.

3- Bennet HS. The microscopical investigation of biological materials with polarized light. In: Jones RM. Mc Clung's handbook of microscopical technique. New York: Hafner Publishing CO; 1967. p 591-677.

4- Bernstein EF, Sullivan FJ, Mitchell JB, Salomon GD, Glatstein E. Biology of chronic radiation effect on tissue and wound healing. Clin Plast Surg. 1993 July;20(3):435-53.

5- Boldyrev AA. Does carnosine possess direct antioxidant activity? Int J Biochem. 1993 Aug;25(8):1101-7.

6- Bóscolo FN, Almeida SM, Vizioli MR, Lourenço RM, Monteiro SAP. Efeito de baixas doses de radiação X em feridas suturadas e não suturadas-estudo experimental em ratos. Pesq Odontol Bras. 2000 out/dez;14(4):386-91.

7- Drake DB, Oishi SN. Wound healing considerations in chemotherapy and radiation therapy. Clin Plast Surg. 1995 Jan;22(1):31-7.

8- Edwars JE. Methods for the demonstration of intercellular substances of the connective tissues. In: Jones RM. Mc Clung's handbook of microscopical technique. New York: Hafner Publishing CO; 1967. p.240-68.

9- Felemovicius I, Bonsack ME, Baptista ML, Delaney JP. Intestinal radioprotection by vitamin E (Alpha-tocopherol). Ann Surg. 1995;222:504-10.

10- Fitzpatrick DW, Fisher H. Carnosine, histidine, and wound healing. Surgery. 1982 Jan;91(1):56-60. 
11- Fuji A, Cook ES. Prodiotics. Antistaphylococcal and antifibrinolytic activies of ù-guanidoacyl 1- histidines. J Med Chem. 1973 Dec;16(12):1409-11.

12- Guidugli-Neto J. The effect of Roentgen radiation on the capillary sprouts and superficial loops of granulation tissue. Quantitative study of the vascular volume. Rev Fac Odontol Univ São Paulo. 1987 out/ dez;1(4):6-8.

13- Hipkiss AR, Brownson C, Carrier MJ. Carnosine, the anti-aging, anti-oxidant dipeptide, may react with protein carbonyl groups. Mech Ageing Dev. 2001 Sept;122(13):1431-45.

14- Manzi FR, Bóscolo FN, Almeida SM, Tuji FM. Estudo morfológico do efeito radioprotetor da vitamina $\mathrm{E}$ (dl-alfa-tocoferil) na reparação tecidual em ratos. Radiologia Brasileira. 2003;36:367-71.

15- Miller SH, Rudolph R. Healing in the irradiated wound. Clin Plast Surg. 1990 July;17(3):503-8.

16-Moore MJ. The effect of radiation on connective tissue. Otolaryngol Clin North Am. 1984 May;17(2):389-98.

17- Moyer KE, Davis A, Saggers GC, Mackay DR, Ehrlich HP. Wound healing: the role of gap junctional communication in rat granulation maturation. Exp Mol Pathol. 2002;72:10-6.

18- Mukkada AJ, Nutini LG, Cook ES. Prophylactic effect of ãaminobutyrylhistidine (homocarnosine) on the experimental staphylococcal infections in mice. Appl Microbiol. 1969 Oct;18(4): 641-5.

19- Mustoe TA, Porras-Reyes BH. Modulation of wound healing response in chronic irradiated tissues. Clin Plast Surg. 1993 July;18(3):465-71.

20 - Nagai K, Suda T, Kawasaki K, Mathuura S. Action of carnosine and â-alanine on wound healing. Surgery. 1986 Nov;100(5):815-21.

21 - Pohle EA, Ritchie G, Moir WW. Studies of the effect of Roentgen rays on healing of wounds. I. Histological changes in skin wounds in rats following. Postoperative irradiation with very small and moderated doses. Radiology. 1949;52:707-13.

22- Qu J, Cheng T, Shi C, Lin Y, Yan G, Ran X. Reduced presence of tissue repairing cells in wounds combined with whole-body irradiation injury is associated with both suppression of proliferation and increased apoptosis. Med Sci Monit. 2003;9:370-7.

23- Reinhold MD, Buisman GH. Radiosensitivity of capillary endothelium. Br J Radiol. 1973 Jan;46(541):54-7.

24- Ritchie G. Effect of roentgen irradiation on the healing of wounds. Arch Path. 1933;16:839-51.

25- Rudolph R, Vande Berg J, Schneider JA, Fischer JC, Poolman WL. Slowed growth of cultured fibroblasts from human radiation wounds. Plast Reconstr Surg. 1988 Oct;82(4):669-75.

26- Silaeva SA, Guliaeva NV, Khatsernova B Ia, Onufriev MV, Nikolaev A Ia. Effects of 4-methyluracil and carnosine on healing of skin wounds in rats. Bull Eksp Biol Med. 1990;109(2):180-2.

27- Tamba M, Torreggiani A. A pulse radiolysis study of carnosine in aqueous solution. Int. J Radiat Biol Oncol Phys. 1998 Sept;74(3):33040 .

28- Tibbs MK. Wound healing following radiation therapy: a review. Radiother Oncol. 1997 Feb;42(2):99-106.

29- Vizioli MR. Macromolecular organization of rat sponge-induced granulation tissue as reveled by dicroism. Acta Anat (Basel). 1971 Nov;80:73-80.
30- Vizioli MR, Almeida OP. Effects of carnosine on the development of rat sponge-induced granulation tissue. I. General morphology and glicosaminoglycans histophotometry. Cell Mol Biol. 1978;23(3):26773

31- Wang Q, Dickson GR, Abram WP, Carr KE. Electron irradiation slows down wound repair in rat skin: a morphological investigation. Br J Dermatol. 1994 May;130(5):551-60.

32- Weiss JF, Landauer MR. Radioprotection by antioxidants. Ann NY Acad Sci. 2000;899:44-60. 